\title{
Determinant analysis of MSMEs credit in Indonesia
}

\author{
Prasetiono ${ }^{1}$ and Anisa Puspa Dina ${ }^{2}$ \\ 1,2Department of Management, Faculty of Economics and Business, Universitas Diponegoro, Indonesia
}

\begin{abstract}
This study was conducted to analyze several variables as the determinants of credit of micro, small, and medium enterprises (MSME) in Indonesia. Those variables are society income, geographic branch penetration (GBP), demographic branch penetration (DBP), credit account per capita (CAC), and deposit account per capita (DAC) of commercial banks. The samples used in this study are 33 Provinces in Indonesia in the period 20132017 using the purposive sampling technique. We examined data uses the non-participant observation method by directly quoting financial, GRDP, banking, geographical, and demographic data. The analysis used in this research is multiple linear regression consisting of the classic assumption test, $\mathrm{F}$ test, t-test, and hypothesis testing. This study indicated that society income, CAC, and DBP have a positive and significant effect on MSME credit. In contrast, GBP has a positive but non-significant effect on MSME credit, and DBP has a significant negative effect on MSME credit.
\end{abstract}

Keywords

MSME credit; society income; geographic branch penetration; demographic branch penetration; credit account per capita; and deposit account per capita

\section{INTRODUCTION}

Micro, small, and medium enterprises (MSME), like in other countries, have an essential role in the Indonesian economy. However, MSME still has dealt with various problems; one of the most significant problems is the lack of funds. The lack of funds issues can be overcome by using MSME credits, a lending and borrowing activity between creditors to micro, small, and medium business debtors who meet the definition and criteria of micro, small and medium businesses as stipulated in Law No. 20/2008. Besides, MSME loans have a vital role for MSME to sustain the businesses because MSME loans have a significant effect on the growth of MSME (Ayuba \& Zubairu, 2015).

To ease MSME in getting loans, the Indonesian government launched a financial inclusion program. One of this program's objectives is to increase MSME access to formal financial services within the framework of inclusive and equitable economic development (Otoritas Jasa Keuangan, 2016). At this point, banking industries play a significant role in distributing MSME credit (www.bi.go.id, accessed on 18 November 2020). Banks are encouraged to increase the amount of credit for MSME, which will support Indonesian economic

development (finansial.bisnis.com, accessed on 18 November 2020). Therefore, Indonesia's bank managers must have information regarding factors that determine MSME credit performance. However, to the best of our knowledge, there are limited studies that comprehensively examine this issue in an Indonesian context. This study aims to fill this gap by examining several variables as the credit determinants of MSME in Indonesia.

Previous studies showed that one of the most prominent factors determining the MSME credit is society income and factors related to financial inclusion. Financial inclusion has three dimensions: the access dimension (geographic branch penetration/GBP and demographic branch penetration/DBP), the usage dimension (use of credit account per capita/CAC, and deposit account per capita/DAC), and the quality dimension. The first dimension of financial inclusion is the dimension of access. The access dimension is the ability to use formal financial services in terms of physical affordability, such as bank offices, ATMs, and financial service agents and expenses. The access dimension has a large role in the availability of bank and ATM offices in Indonesia's regions. There are two indicators on this dimension, na,l mely geographical and demographic. Geographical indicators include GBP and 
DBP (The World Bank, 2004). The second dimension of financial inclusion indicators is the usage dimension. The usage dimension measures the use of financial services. The use of financial services can be measured by several indicators, including using a CAC and a DAC (The World Bank, 2004).

In this study, society income and financial inclusion indicators will be used as an independent variable that influences MSME credit as the dependent variable. The financial inclusion indicators used are the access dimensions and usage dimensions. They are in GBP and DBP as access dimensions, use of CAC, and DAC usage as usage dimensions. Society income is inferred to affect MSME credit because it is highly considered in determining a person's eligibility in taking and returning credit. The level of credit obtained by someone is following the level of income. The level of financial inclusion in an area is influenced by the level of society income, meaning that the better society income, the greater the possibility of the society accessing financial services (Fungáčová \& Weill, 2014). GBP is supposed to affect MSME credit due to the measurement of the banking system's geographical penetration indicator by looking at the number of bank branches per $1000 \mathrm{~km}^{2}$.

The calculation value results indicate that the higher the ratio value, the closer the society's distance to the bank branch office, which means the more bank branches. The more bank branches, the more efficiently the society will receive financial services such as MSME credit. The banking system's demographic penetration is supposed to affect MSME credit due to the GBP indicator's measurement by looking at the number of bank branches per 100,000 adult population. The higher the calculation results indicate, the fewer people served in each bank branch office. The fewer people served in each bank branch office, the more bank branch offices, ease people receiving financial services such as MSME credit. The use of credit account is supposed to affect MSME credit because the measurement of account use indicators looks at the number of commercial bank credit accounts per 1000 adult population. This indicator illustrates the use of credit services by society. The higher the value of using a credit account, the more people use financial products and services. The more people who have credit accounts and financial services, the greater the potential for MSME credit to banks. DAC (savings, current accounts, and deposits) is supposed to affect MSME credit because this indicator is measured by looking at the number of DAC of commercial banks per 1000 adult population. This indicator illustrates the use of DAC services by society. The higher the value of using DAC, the more people will use financial service products, which means the potential for a more significant number of MSME credits to be distributed. Revenue, geographical branch penetration, DBP, use of credit accounts, and DAC use are supposed to affect MSME credit so that it becomes an independent variable and MSME credit as the dependent variable. Therefore, it is necessary to know each variable's development in Indonesia.

Each variable's development is related to Indonesia's level of regional income and financial inclusion conditions. The development of MSME credits in Indonesia increases the number of loans extended. Credit development had a very rapid increase, which amounted to more than 100 percent from 2010 to 2011. From 2011 to 2012, it increased by around 15 percent. From 2012 to 2013, MSME credits increased by around 15 percent.

However, the increasing development of MSME credits does not guarantee equal distribution of MSME credits in all Indonesian regions. This is because an increase in MSME credits distributed does not coincide with equal distribution. The distribution of MSME credits in all provinces in Indonesia is currently not evenly distributed, so some regions have received MSME credits in large amounts. However, some regions have received MSME credits in small amounts. The unequal distribution of MSME credit is included in the underbanked category. Under-banked is a person who has minimal access or does not have access to financial services. That is because only about $36 \%$ of Indonesia's adult population has access to formal financial institutions based on the 2014 Global Findex Data (Otoritas Jasa Keuangan, 2016). Besides, as many as $60-70 \%$ of MSME actors do not yet have access to bank credit, only 30 percent (Nu \& Le, 2012).

The deployment and distribution of MSME credits are also related to Indonesia's distribution of bank branches. This relates to the variables of geographical branch penetration and DBP. There is an imbalance 
of banking access between regions in Indonesia. Some areas are still in the underbanked category, such as North Sumatra, Riau, and Central Kalimantan, and others are in the overbanked category, such as Java and Bali (Bank Indonesia, 2013). This indicates that Geographical Branch Penetration and Demographics Branch Penetration in Indonesia are still not evenly distributed since there are people who have difficult access to banking and some are easy. The uneven distribution of bank offices in Indonesia also affects the variable use of credit accounts and DAC. This means that credit accounts and DAC use in Indonesia are still uneven. The uneven distribution of bank offices impacts MSME credit deployment, which is less optimal.

Another variable that needs to be known for its development is society's income. Society income used in this study is regional income for each province or GRDP. GRDP, according to the Central Statistics Agency (BPS), is gross value added arising from all economic sectors or all business units in an area. GRDP during the last 5 years, from 2013 to 2017, has increased in almost all provinces.

Similar studies with various variables have been previously studied by Ghosh (2011), Chakravarty \& Pal (2013), Khan (2011), Sharma (2016), Togba (2012), Fahmy, Rustam \& Asmayadi (2016), Rahman \& Widyarti (2017) ), and Alimi (2018) with different research results. An empirical phenomenon regarding the factors that affect MSME credit is experiencing fluctuations and inconsistencies from previous studies (research gap). The difference in variables, research objects, and years of research is the basis for reresearching the factors that affect MSME credit. This study aims to analyze the effect of society income, GBP, DBP, CAC, and DAC of commercial banks on MSME credits in Indonesia from 2013 to 2017.

\section{LITERATURE REVIEW AND HYPOTHESES DEVELOPMENT}

\section{The impact of society income on MSME credit}

Income becomes one of the things that is highly considered in determining a person's eligibility to take and return credit. The level of credit obtained by someone adjusts to the level of income. This is supported by the theory of "The Six C's of credit" one of the instruments is capital that has income. The level of financial inclusion in an area is influenced by the level of society income, meaning that the better society's income, the greater the community's possibility of accessing financial services (Fungáčová \& Weill, 2014). Besides, based on Togba (2012) research, the results revealed a positive relationship between income and credit loans used by society.

H1: Society income has a positive impact on MSME credit

\section{The impact of GBP on total MSME credit}

In increasing public use of financial services, which means increasing financial inclusion in Indonesia, GBP can increase the amount of use of financial services by society. This can be noticed based on the banks' geographical penetration indicators, namely, looking at the number of bank branches per $1000 \mathrm{~km} 2$. The calculation value results indicate that the higher the ratio value, the closer the distance of the society to the bank branch office, which means more bank branches. The more bank branches, the more easily the public will receive financial services such as MSME credit. Supported by the theory of the Optimal Industrial Location of Losch stated that Losch is concerned with the ease of access that buyers will get both in terms of distance and transportation expenses which also determine demand and sales. When the company's distance is further from the market, consumers will be more reluctant to buy because of the high expense of transportation to distant places. The optimal industry location theory is related to the relationship between the geographical penetration variables of banks and MSME loans where branch offices or ATMs are closer to the public and business operators, thus facilitating access and increasing demand while increasing the use of services and products including MSME credits.

An increase in the number of people and businessmen who can access MSME credit will increase the number of credit customers, directly or indirectly increasing the number of MSME credits distributed. This means that when people have good geographical access to banks, it will increase banking services, one of which is MSME credit. 
Therefore, the GBP has a positive relation with MSME credit. This is supported by previous research that shows a positive relationship between the GBP and the number of MSME credits distributed. The research was conducted by Ghosh (2011), Togba (2012), Chakravarty \& Pal (2013), Sharma (2016), Rahman \& Widyarti (2017).

\section{H2: GBP has a positive impact on MSME credit}

\section{The impact of DBP on the total MSME credits}

In increasing the use of financial services, which means increasing financial inclusion in Indonesia, DBP can increase the number of people who use financial services. This can be noticed based on the measurement of the banking system's geographical penetration indicators that are looking at the number of bank branches per 100,000 adult population. The higher the calculation results, the fewer people served in each bank branch office. The fewer people served in each bank branch office, the more the bank branch office, ease the society to receive financial services, one of which is MSME credit. The Optimal Industry Location theory supports this from Losch, which states that Losch places importance on the ease of access that buyers will get, both in terms of distance and transportation costs, determining demand and sales. If the company's distance is further from the market, consumers will be more reluctant to buy because of the high cost of transportation to distant places. The optimal industry location theory is related to the relation between the demographic penetration of banks and MSME credits. If branch offices or ATMs are closer to the public and consumers, it will facilitate access, increase demand, and increase the use of services and products, including MSME credits. This can reduce the number of people served by each branch due to easier access to society and the evener distribution of bank branches. An increase in the number of people and businesses that can access MSME credits will increase the number of credit customers that can directly or indirectly result in an increase in the number of MSME credits distributed.

This is in line with previous studies, showing a positive relationship between DBP with MSME credit. The study was conducted by Ghosh (2011), Sharma (2016), Fahmy, Rustam, \& Asmayadi (2016).

\section{H3: DBP has a positive impact on MSME} credit

\section{The impact of CAC of commercial bank on the total MSME credit}

CAC or the use of per capita credit accounts is one indicator in the dimensions of use in financial inclusion measures. This indicator is measured by looking at the number of commercial bank credit accounts per 1000 adult population. This indicator illustrates the use of credit services by society. The higher the value of using a credit account, the more people will use financial products and services. The more people have credit accounts and financial services, the greater the use of financial services, and the potential for distributing MSME credits to banks is greater. This is in line with the theory of modern financial intermediaries from Andries, which states that the society or business people who receive funds are credit customers whom banks will target to distribute funds in the form of credit, including MSME credits. Besides, this is also in line with previous research where there is a positive relationship between credit accounts' uses with MSME credits. The study was examined by Ghosh (2011), Sharma (2016), and Alimi (2018).

H4: CAC has a positive impact on the total MSME credit in Indonesia

\section{The impact of DAC of commercial banks on the total MSME credit}

DAC or the use of DAC is one indicator in the dimensions of use in financial inclusion measures. This indicator is measured by looking at the number of commercial bank deposits per 1000 adult population. This indicator illustrates the use of DAC services by society. The higher the value of using DAC, the more people will use financial service products, which indicates the potential for the more significant number of MSME credits that can be distributed. This is in line with the theory of modern financial intermediaries by Andries states that the final banking product is a credit given to the debtor. The primary input is funded in the form of deposits obtained from banks. 
Therefore, more DAC use means that more funds are distributed MSME credit. This is in line with previous studies results, where DAC is positively related to MSME credits. The study was conducted by Ghosh (2011), Li, Li, Huang, \& Zhu (2013), Sharma (2016), Fahmy et al. (2016), Alimi (2018).

H5: DAC has a positive effect on the total MSME credit

\section{METHODS}

\section{Data collection}

This study's sample is 33 provinces because there is one province, North Kalimantan, which has the incomplete required data, so it does not fulfill the requirements. Observation data are annual data released by Otoritas Jasa Keuangan (OJK) or the Financial Services Authority, Bank Indonesia (BI) and Badan Pusat Statistik (BPS) or the Central Statistics Agency in 2013-2017. Data that were processed are 165 data obtained from 33 provinces in Indonesia multiplied by five, namely the fiveyear research period from 2013 to 2017.

\section{Measurements}

\section{MSME credit}

The definition of MSME credit is a lending and borrowing activity between creditors to micro, small and medium business debtors who meet the definition and criteria of micro, small and medium businesses as stipulated in Law No. 20 of 2008 concerning MSMEs (Bank Indonesia, n.d.). MSME Credit can be measured using the following formula (Alimi, 2018):

\section{Total MSME Credit $=$ Ln (The number of MSME loans distributed annually)}

\section{Society income}

Income is the amount of money earned by the community due to the activities or work carried out. Income is one of the factors that influence people in conducting credit. According to research (Fungáčová \& Weill, 2014) using a country's gross domestic product level in measuring income levels, as well as research from (Rahman \& Widyarti, 2017) using the City and Regency Gross Regional Domestic Product in Central Java in measuring income levels. Therefore, income in this study is measured from the level of provincial GRDP (Rahman \& Widyarti, 2017)

Society Income $=$ Provincial GRDP in Indonesia $G R D P=G R D P$ Value based on the Applicable Price of each Indonesian Province

\section{Geographic branch penetration (GBP)}

GBP is one indicator of access dimension measurement that reflects how close the community is to a bank branch office in terms of geographical access. This indicator can be measured by the following formula (The World Bank, 2004):

$$
G B P=\frac{\text { Number of Bank offices (unit) }}{\text { Area Size }\left(K M^{2}\right)} \times 1000
$$

\section{Demographic branch penetration (DBP)}

DBP is one indicator of the measurement of access dimensions that compares bank office units to adult residents in an area. This indicator reflects how much the community can be served by each bank branch office. The higher the value, it shows that there are fewer people served by each branch so that it can be said that access is easier. The formula that can be used for this indicator is (The World Bank, 2004)

$D B P=\frac{\text { Number of Bank offices (unit) }}{\text { Adult Population (people) }} \times 100.000$

\section{Credit account per capita (CAC)}

CAC is one indicator of financial inclusion measures, namely the dimensions of usage. This indicator is measured by looking at the number of commercial bank credit accounts per 1000 adult population and reflects the number of people who have credit accounts and use financial services in the form of credit. The higher the calculation results, the more people will use credit. The formula used in the calculation of this indicator is (The World Bank, 2004)

$$
C A C=\frac{\text { Number of Credit Accounts (account) }}{\text { Adult Population (people) }} \times 1000
$$




\section{Deposit account per capita (DAC)}

DAC is one indicator of financial inclusion measures, namely the dimensions of usage. This indicator is measured by looking at the number of commercial bank deposits per 1000 adult population and reflects the number of people who have deposits (savings, time deposits and demand deposits) and use financial services in the form of deposits. The higher the calculation results, the more people will use DPK services. The formula used in the calculation of this indicator is (The World Bank, 2004)

$$
D A C=\frac{\text { Number of Deposit Account (account) }}{\text { Adult Population (people) }} \times 1000
$$

\section{Data Analysis}

The data analysis method in this research is using multiple linear regression techniques. This technique is to determine the presence or absence of more than one independent variable with the dependent variable. The regression equation in this study is as follows:

$$
\begin{gathered}
C R E D I T=a+b 1 P D R B+b 2 G B P+b 3 D B P+ \\
b 4 C A C+b 5 D A C+e
\end{gathered}
$$

Where:

$$
\begin{array}{ll}
\text { Credit } & =\text { Total MSME credit } \\
\text { a } & =\text { constant } \\
\text { b1 }- \text { b4 } & =\text { regression coefficient } \\
\text { GRDP } & =\text { Society income } \\
\text { GBP } & =\text { Geographic branch penetration } \\
\text { DBP } & =\text { Demographic branch penetration } \\
\text { CAC } & =\text { Credit account per capita } \\
\text { DAC } & =\text { Deposit account per capita } \\
\text { e } & =\text { residual variable }
\end{array}
$$

\section{RESULTS AND DISCUSSION}

Table 1 shows the results of the descriptive analysis. The GDP referred to in Table 1 is the income of the people who have the appropriate data presented in the table in billions of rupiah. The minimum value is 21439.00 and the maximum value is 2410373.00. The average value is 356211.0970 and the standard deviation value is 504484.29636 .

The geographical penetration variable described by GBP is used as X1, has data and results presented in the form of ratios. The GBP variable has a minimum value of 0.17 , a maximum value of 820.77 , an average value of 27.4819 , and a standard deviation of 135.33245. The DBP variable described in the table with DBP is used as $\mathrm{X} 2$, has data and results presented in the form of ratios. The GBP variable has a minimum value of 1.02 , a maximum value of 7.05 , an average value of 2.4714 , and a standard deviation of 1.13063 .

Credit account per capita of commercial bank, wherein the table is described with the CAC explained in the form of a ratio. The CAC variable has a minimum value of 70.00 , a maximum value of 2524.00 , an average value of 192.6909, and a standard deviation value of 400.44065 . The deposit account per capita of commercial banks wherein the table becomes DAC has the calculation result in a ratio. DAC has a minimum value of 8.00 , a maximum value of 501.00 , an average value of 50.8667 , and a standard deviation value of 80.13035 . The MSME credit variable or symbolized by credit, is the dependent variable and data presented in the form of currency units in billions of rupiah. The minimum value is 1458.70 and the maximum value is 143959.90 . The

Table 1.

Descriptive Statistics

\begin{tabular}{lcllll}
\hline & $\mathbf{N}$ & Minimum & Maximum & \multicolumn{1}{c}{ Mean } & Std. Deviation \\
\hline GRDP & 165 & 21439.00 & 2410373.00 & 356211.0970 & 504484.29636 \\
GBP & 165 & .17 & 820.77 & 27.4819 & 135.33245 \\
DBP & 165 & 1.02 & 7.05 & 2.4714 & 1.13063 \\
CAC & 165 & 70.00 & 2524.00 & 192.6909 & 400.44065 \\
DAC & 165 & 8.00 & 501.00 & 50.8667 & 80.13035 \\
CREDIT & 165 & 1458.70 & 143959.90 & 24957.0642 & 33747.92946 \\
Valid N & 165 & & & & \\
\hline
\end{tabular}


average value of the MSME credit variable is 24957.0642 and the standard deviation is 33747.92946.

Simultaneous Significance Test Results or F Test can be seen in Table 2, where the calculated $F$ value is 581.264 and the $F$ table value is 2.27. The $F$ table value is calculated from the df 1 (numerator) value of $\mathrm{k}-1$ and the $\mathrm{df} 2$ (denominator) value of $\mathrm{nk}$, with $\mathrm{k}$ as the number of variables and $n$ as the number of observations. The calculated $F$ value is greater than the $\mathrm{F}$ table, which shows that the independent variable has a simultaneous effect on the dependent variable. Furthermore, the model's significance level is 0,000 which means it has a value $<0.05$. This indicates that all independent variables have a simultaneous influence on the dependent variable and there are no problems in the regression model and have fulfilled the model's feasibility assumptions.

Determination Coefficient Test Results or $r$ square can be found in Table 3. which has the Adjusted R Square value of 0.946 . This shows that MSME credit variations can be explained by independent variables such as society income, GBP, Demographics Branch Penetration (DBP), Use of Credit Accounts per Capita of Commercial Bank (CAC), and Use of Deposit Account per Capita of Commercial Bank (DAC) of 946 percent. Besides, the remaining 5.4 percent is explained by other variables not included in the model in this study. The adjusted $r$ square result of 84.6 percent was due to a large independent variable on the dependent variable, especially on the income variable. The magnitude of each independent variable's effect to the

Table 2.

Significance Test Results (F Test)

\begin{tabular}{llllll}
\hline \multicolumn{1}{c}{ Model } & Sum of Squares & df & Mean Square & F & Sig. \\
\hline 1 Regression & 48.273 & 5 & 9.655 & 581.264 & $.000^{\mathrm{b}}$ \\
Residual & 2.641 & 159 & .017 & & \\
Total & 50.914 & 164 & & & \\
\hline
\end{tabular}

a. Dependent Variable: Credit

b. Predictors: (Constant), DAC, DBP, CAC, GRDP, GBP

Table 3.

Results of Determination Coefficient Test $\left(\mathbf{R}^{2}\right)$

\begin{tabular}{lccccc}
\hline Model & $\mathbf{R}$ & R Square & $\begin{array}{c}\text { Model Summary } \\
\text { Adjusted } \\
\text { Square }\end{array}$ & $\begin{array}{c}\text { Std. Error of } \\
\text { the Estimate }\end{array}$ & Durbin-Watson \\
\hline 1 & $.974^{\mathrm{a}}$ & .948 & .946 & .12888 & 2.048 \\
\hline a. Predictors: (Constant), DAC, DBP, CAC, GDRP, GBP \\
b. Dependent Variable: Credit
\end{tabular}

Table 4.

Statistical Test Results t

\begin{tabular}{|c|c|c|c|c|c|c|c|c|}
\hline \multicolumn{9}{|c|}{ Coefficients $^{a}$} \\
\hline & \multirow[b]{2}{*}{ Model } & \multicolumn{2}{|c|}{$\begin{array}{l}\text { Unstandardized } \\
\text { Coefficients }\end{array}$} & \multirow{2}{*}{$\begin{array}{c}\text { Standardized } \\
\text { Coefficients } \\
\text { Beta }\end{array}$} & \multirow[b]{2}{*}{$t$} & \multirow{3}{*}{$\begin{array}{l}\text { Sig. } \\
.650\end{array}$} & \multicolumn{2}{|c|}{$\begin{array}{l}\text { Collinearity } \\
\text { Statistics }\end{array}$} \\
\hline & & B & Std. Error & & & & Tolerance & VIF \\
\hline 1 & (Constant) & -.090 & .197 & & -.454 & & & \\
\hline & GRDP & .669 & .038 & .687 & 17.548 & .000 & .213 & 4.695 \\
\hline & GBP & .016 & .033 & .022 & .467 & .641 & .153 & 6.542 \\
\hline & DBP & -.860 & .129 & -.286 & -6.686 & .000 & .178 & 5.618 \\
\hline & CAC & .192 & .097 & .090 & 1.986 & .049 & .160 & 6.249 \\
\hline & DAC & .375 & .081 & .241 & 4.605 & .000 & .119 & 8.389 \\
\hline
\end{tabular}

a. Dependent Variable: Credit 
dependent variable can be seen in the statistical test t result.

Based on table 4, the results of the statistical t-test at a significance level of $5 \%$ or 0.05 after data transformation and autocorrelation treatment with Cochrane Orcutt showed that there were still insignificant results. There is an insignificant variable because it has a value above 0.05 , namely the GBP.

\section{DISCUSSION}

The hypothesis formulated in $\mathrm{H} 1$ is society income or in the table is the GRDP has a positive effect on MSME Credit. Based on the t-test results obtained, GRDP value indicates the calculated $t$ value of 17.548 means that the value is greater than the $t$ table and a significance level of 0.000 , which means the value $<0.05$. This indicates that Society Income significantly influences MSME Credit as the dependent variable. The coefficient value of 0.669 shows that the higher the level of Society Income in an area, the higher the level of use of MSME Credit by the society in the formal financial institutions. Therefore, the results obtained that society income positively and significantly affects MSME Credit, then $\mathrm{H} 1$ is supported. The hypothesis results are supported by the 6C's of Credit concept, in which one of the instruments contained in the theory is capital, which has income in it. The level of financial inclusion in an area is affected by society's level of income, meaning that the better the income, the greater the number of people accessing financial services (Fungáčová \& Weill, 2014). Besides, based on Togba (2012) research, the results revealed a positive relationship between income and credits used by society.

The hypothesis formulated in $\mathrm{H}_{2}$ is the GBP has a positive effect on MSME Credit. Based on the t-test results obtained the value of GBP or in the table symbolized by GBP, the $t$ value of 0.467 means that the value is smaller than the $t$ table and the significance level of 0.641 which means the value is $>0.05$. This indicates that the GBP has no significant effect on MSME credits as the dependent variable. The coefficient value of 0.016 indicates that the higher the level of GBP or the distribution of the number of bank branches in a region, the higher the level of use of MSME Credit by the society in the formal financial institutions. GBP has not a significant positive effect on MSME Credit. Therefore, it can be said that the results of the t-test are not following $\mathrm{H} 2$ is not supported. T-test results are also following the theory of geographical penetration measurement and the theory by August Losch, namely the Optimal Industrial Location, which states that the farther a company from the market, the consumer will be more reluctant to buy due to high transportation costs. In other words, there is a positive relationship between access or GBP and the use of financial services by the public, one of which is the MSME Credit. Hypothesis test results that are in line with the theory of GBP measurement and the theory of optimal industrial location but do not have significant results can be caused by data variations that are relatively small and insignificant. This affects the insignificant effect of the GBP on MSME credits. This is in line with the results of previous studies conducted by Li et al., (2013) and Alimi (2018) and which shows GBP has a positive and not significant effect on total MSME credits.

The hypothesis formulated in $\mathrm{H} 3$ is that DBP has a positive effect on MSME Credit. DBP or in a table symbolized by DBP shows the t value of -6.668 , meaning that the value is greater than the table. Furthermore, the significance level is 0.000 , which means the value is $<0.05$. This indicates that it significantly influences MSME Credit as the dependent variable. The coefficient value of -0.860 indicates that the higher the level of DBP in a region, the lower the level of MSME Credit usage by the society in the formal financial institutions. Based on the results of the t-test, it was found that GBP had a significant negative effect on MSME Credit. Therefore, it can be stated that the results of the t-test showing that $\mathrm{H} 3$ is not supported. T-test results are also not following the theory of measurement of DBP. DBP measurement theory explains a positive relationship between GBP with MSME credit. Therefore, the higher the DBP, the higher the MSME credit level. Besides, the test results are not in line with the theory put forward by August Losch namely the Optimal Industry Location, which states that the farther the company from the market, the more consumers will be reluctant to buy due to the high cost of transportation. In other words, there is a positive relationship between ease of access, which means that fewer people are served in one bank branch 
office, the more public can easily access the bank office with the use of financial services, one of which is MSME credits. This is in line with previous studies conducted by Alimi (2018) which showed that the DBP had a negative and significant effect on MSME credits.

The hypothesis formulated in $\mathrm{H} 4$ is that the use of CAC has a positive effect on MSME credits. The CAC symbolizes the variable of CAC Usage or in the table, showing the $t$ value of 1.986 means that the value is greater than the value of the $t$ table and a significance level of 0.049 which means the value is $<0.05$. This indicates that the use of CAC has a significant effect on MSME Credit as the dependent variable. The coefficient value of 0.192 indicates that the higher the use of credit account of commercial banks or the more people who have credit accounts at commercial banks, the higher the use of MSME Credit by the public at formal financial institutions. Based on the results of the t-test, the results show that the use of CAC has a positive and significant effect on MSME Credit so that $\mathrm{H} 4$ is supported. This is in line with the theory of modern financial intermediaries from Andries, which states that the public or business people who receive funds are credit customers whom banks will target to distribute funds in the form of credit, including MSME credits. Besides, this is also in line with previous research where there is a positive relationship between credit accounts per capita with MSME credits. The study was examined by Ghosh (2011), Sharma (2016), and Alimi (2018).

The hypothesis formulated in $\mathrm{H} 5$ is that the use of DAC has a positive effect on MSME Credit. The DAC variable's use shows the value of the $t$ arithmetic of 4.605 means that the value is greater than the value of the t table and a significance level of 0.000 , which means the value is $<0.05$. This indicates that the use of DAC of commercial banks significantly influences MSME Credit as the dependent variable. The coefficient value of 0.375 indicates that the higher the DAC level of commercial banks or the more people who have DACs at commercial banks, the higher the level of use of MSME Credit by the public at formal financial institutions. Based on the results of the t-test, the results show that the use of DAC has a positive and significant effect on MSME credit so that $\mathrm{H} 5$ is supported. This is in line with the theory of modern financial intermediaries by Andries, where the final banking product is a credit given to the debtor and the primary input is supported in the form of deposits obtained from banks. Therefore, the more DAC use, the more funds are distributed, one of which is MSME credit. This is in line with previous studies results, where DAC is positively related to MSME credit. The study was conducted by Ghosh (2011), Li, Li, Huang, \& Zhu (2013), Sharma (2016), Fahmy et al. (2016), Alimi (2018).

\section{CONCLUSION}

The purpose of this study is to determine the effect of independent variables in the form of society income, Geographic Bank Penetration, Demographic Bank Penetration, Use of CAC of Commercial Bank, and Use of DAC of Commercial Bank on the total MSME Credit in Indonesia as the dependent variable. The sample used in this study amounted to 165 observational data obtained from 33 provinces in Indonesia from 2013 to 2017. Society income has a positive and significant effect on total MSME credits. This indicates that the higher the level of society income, the higher the MSME credit level. Since the higher the level of society income, the higher the use of formal financial services, MSME credit. Therefore, the first hypothesis is proven. GBP has a positive and significant effect on total MSME credits. This indicates that the higher the GBP level of banks or the distribution of the number of bank branches in an area, the higher the level of MSME credit usage by the public in the formal financial institutions. The research results obtained are the GBP positive and not significant effect on MSME credits. Insignificant relationship due to the variation of variable data that is not significant affects the research results, the second hypothesis $(\mathrm{H} 3)$ is not supported.

DBP has a positive and significant effect. However, the research results obtained are the DBP negatively and significantly affect MSME credits. This indicates that the higher the level of DBP in an area, the lower the level of MSME Credit usage by the public in the formal financial institutions. This is due to the development of the digital era at the moment with online credit and increasing the use of online banking activities. Therefore, the third hypothesis $\left(\mathrm{H}_{3}\right)$ is rejected. 
The use of a Credit Account has a positive effect on the total MSME credit. This indicates that the higher the level of use of CAC of commercial banks or the more people who have credit accounts at commercial banks, the higher the public's level of MSME Credit usage at formal financial institutions. Therefore, the fourth hypothesis $(\mathrm{H} 4)$ is supported.

The use of DAC accounts has a positive effect on total MSME credit. This indicates that the higher the level of use of DAC accounts of commercial banks or the more people who have credit accounts at commercial banks, the higher the level of use of MSME Credit by the public at formal financial institutions. Therefore, the fifth hypothesis (H5) is accepted.

Just like other studies, this study undeniably. Among others, the first adjusted square value indicates society income, GBP, DBP, use of CAC, and use of DAC accounts for MSME credit. The adjusted $r$ square value is 94.6 percent. This indicates that other variables outside the study of 5.4 percent can affect MSME credit. Second, the period used is only five years, from 2013 to 2017. Therefore, when other studies are carried out with different periods, both longer and different observation years, then there is a possibility the results provided will also be different. Third, the number of samples used tends to be limited because it follows the number of provinces in Indonesia. Fourth, this research has not compared interprovinces.

\section{Recommendation}

It is expected that the banking sector will be able to further expand bank branch offices in all regions in Indonesia, particularly in regions where there are still a small number of bank branch offices. Therefore, equitable banking services can be provided to the public to increase financial inclusion in the community. Micro, small and medium businesses and prospective entrepreneurs are expected to consider the business location based on the availability and ability to access financial services, particularly banks, which can be used as an alternative procurement of business capital and transaction media that can help business growth.

Further studies are expected to: first, use variations of variables not found in this study to obtain varied results and different measurements such as education levels and interest rates in the journal Rahman \& Widyarti (2017). Second, further research can use different observation year periods, both longer and different observation years so that it can produce more, more diverse data and more valid testing. Third, further research can use different scope variations, such as variations in the scope of the area contained in the journal Rahman \& Widyarti (2017) where the variation used is the City and Regency in Central Java.

\section{REFERENCES}

Alimi, L. H. (2018). Penggunaan Rekening Kredit dan Penggunaan Rekening DPK Bank Umum terhadap Kredit UMKM di Indonesia ( Studi Kasus Tahun 20122016 ) SKRIPSI.

Andrieş, A. M. (2009). Theories regarding financial intermediation and financial intermediaries-a survey. The USV Annals of Economics and Public Administration, 9(2), 254-261.

Ayuba, B., \& Zubairu, M. (2015). Impact of Banking Sector Credit on the Growth of Small and Medium Enterprises (SME's) in Nigeria. Journal of Resources Development and Management Journal, 15, 1-9.

Bank Indonesia. (n.d.). Data Kredit Usaha Mikro, Kecil dan Menengah (Metadata). Retrieved March 11, 2019, from https://www.bi.go.id/id/umkm/kredit/data /Default.aspx

Bank Indonesia. (2013). Evolusi Kerangka Kebijakan Financial Inclusion, (November).

Bank Indonesia. (2014). Booklet Keuangan Inklusif.

Bank Indonesia. (2015). Perkembangan baki debet kredit usaha mikro, usaha kecil, dan usaha menengah (UMKM) perbankan, 1(March 2013), 2013-2015.

Bank Indonesia. (2017). Indikator Kauangan Inklusif.

Chakravarty, S. R., \& Pal, R. (2013). Financial inclusion in India: An axiomatic approach. Journal of Policy Modeling, 35(5), 813-837. https://doi.org/10.1016/j.jpolmod.2012.1 2.007

Danistyo, G. (2009). Analisis Faktor-Faktor yang Mempengaruhi Permintaan dan Penawaran Kredit UMKM di Indonesia. Skripsi. Institut Pertanian Bogor. 
Fahmy, M. obaid, Rustam, M., \& Asmayadi, E. (2016). Pengaruh Keuangan Inklusif Terhadap Kredit yang Disalurkan pada Sektor Usaha Mikro, Kecil dan Menengah di Indonesia. Ekonomi Bisnis Dan Kewirausahaan, 5(2), 118-135.

Fungáčová, Z., \& Weill, L. (2014). Understanding financial inclusion in China. China Economic Review, 34, 196-206. https://doi.org/10.1016/j.chieco.2014.12 .004

Ghosh, S. (2011). Does financial outreach engender economic growth? evidence from Indian states. Journal of Indian Business Research, 3(2), 74-99. https://doi.org/10.1108/1755419111113 2206

Ghozali, I. (2016). Aplikasi Analisis Multivariate dengan Program IBM SPSS 23 (8th ed.). Badan penerbit Universitas Diponegoro.

Gujarati, D. N. (2003). Basic Econometrics.

Li, R., Li, Q., Huang, S., \& Zhu, X. (2013). China Economic Review The credit rationing of Chinese rural households and its welfare loss: An investigation based on panel data is. China Economic Review, 26(37), 17-27. https://doi.org/10.1016/j.chieco.2013.03 .004

Lösch, A. (1954). The Economics of Location, 302.

Muljono, T. P. (2001). Manajemen Perkreditan bagi Bank Komersil. Yogyakarta: BFFEYogyakarta.

Nu, P., \& Le, M. (2012). What Determines the Access to Credit by SMEs? A Case Study in Vietnam. Journal of Management Research, 4(4), 90-115. https://doi.org/10.5296/jmr.v4i4.1838

Otoritas Jasa Keuangan. (2016). Peraturan Presiden Republik Indonesia Nomor 82 Tahun 2016 Tentang Strategi Nasional Keuangan Inklusif, (82), 1-33. https://doi.org/10.1017/CBO978110741 5324.004

Otoritas Jasa Keuangan. (2017). Sp 05/dkns/ojk/1/2017, 1-2.

Rahman, M. I., \& Widyarti, E. T. (2017). Analisis pengaruh pendapatan, pendidikan, suku bunga, penetrasi demografis dan geografis perbankan terhadap kredit umkm.

Sharma, D. (2016). Nexus between financial inclusion and economic growth: Evidence from the emerging Indian economy. Journal of Financial Economic
Policy, $\quad$ 8(1), 13-36. https://doi.org/10.1108/JFEP-01-20150004

Strategi Nasional Keungan Inklusif. (2018). Sistem Kredit UMKM. Retrieved March 29, 2019, from http://snki.ekon.go.id/sistem-kreditumkm/

Sugiyono. (2008). Metode Penelitian Bisnis (Pendekatan Kuantitatif, Kualitatif, dan $R \& D)$. Bandung: Alfabeta, cv.

The World Bank. (2004). Measuring banking sector outreach •. World Bank, 1-7. Retrieved from http://siteresources.worldbank.org/INTT OPACCFINSER/Resources/Banking.pd $f$

Togba, E. L. (2012). Microfinance and households access to credit: Evidence from Côte d'Ivoire. Structural Change and Economic Dynamics, 23(4), 473486.https://doi.org/10.1016/j.strueco.20 12.08.002

www.bi.go,id, accessed on 18 November 2020. https://www.bi.go.id/id/umkm/kredit/Def ault.aspx

www.finansial.bisnis.com, accessed on 18 November 2020. https://finansial.bisnis.com/read/202011 18/90/1319214/pemulihan-ekonomibank-diminta-lebih-berani-salurkankredit-ke-umkm 